\title{
SANITARY QUALITY OF Brachiaria brizantha $c v$. MARANDU AND XARAÉS SEEDS HARVESTED IN DIFFERENT STATES IN BRAZIL
}

\author{
QUALIDADE SANITÁRIA DE SEMENTES DE Brachiaria brizantha cv. MARANDÚ E \\ XARAÉS COLHIDAS EM DIFERENTES ESTADOS DO BRASIL
}

\section{Cibele Chalita MARTINS ${ }^{1}$; Paulo Alexandre Fernandes Rodrigues de MELO $^{2}$; Francisco Elder Carlos Bezerra PEREIRA ${ }^{3}$; Antônio Pereira dos ANJOS NETO ${ }^{4}$; Luciana Cordeiro do NASCIMENTO}

1. Professora da Faculdade de Ciências Agrárias e Veterinárias, FCAV - UNESP, Jaboticabal, SP, Brazil; 2. Doutor pela Faculdade de Ciências Agrárias e Veterinárias, FCAV - UNESP, Jaboticabal, SP, Brazil; 3. Doutorando da Faculdade de Ciências Agrárias e Veterinárias, FCAV - UNESP, Jaboticabal, SP, Brazil. eldercarlos12@ gmail.com; 4. Graduando da Universidade Federal da Paraíba UFPB, Areia, PB, Brazil; 5. Professora a Universidade Federal da Paraíba - UFPB, Areia, PB, Brazil.

\begin{abstract}
The incidence of fungi in seeds depends on the sanitary and climatic conditions in which the seeds were produced. So, the objective of this study was to identify the fungi present in commercial lots of Brachiaria brizantha cv. 'Marandu' and'Xaraés' seeds harvested in different areas in Brazil. Seeds from ten lots of each cultivar, produced in the Brazilian states of Mato Grosso do Sul, Mato Grosso, Goiás, Minas Gerais, São Paulo, and Bahia were evaluated as to moisture content, germination and sanity. The experiment was conducted according to a completely random design with eight replications of 50 seeds for each lot. In both cultivars, the seeds were found to be infected with Aspergillus sp., Chaetomium sp., Curvularia sp., Fusarium sp., and Helminthosporium sp; the highest incidences were those of Chaetomium sp. and Fusarium sp. Seeds of the 'Marandu' cultivar were the only ones showing the presence of Phoma sp. and Pyricularia grisea and those of the 'Xaraés' cultivar with Colletotrichum sp. and Nigrospora sp. The incidence of Fusarium sp., Aspergillus and Nigrospora sp. reduces 'Xaraés' seeds germination whereas it does not interfere in the 'Marandu' seeds germination. The presence of the fungus Pyricularia grisea is for the first time reported in tropical forage grass seeds produced in the Southeast and Northeast regions of Brazil.
\end{abstract}

KEYWORDS: Germination. Forage seeds. Grass forage plants. Production loci.

\section{INTRODUCTION}

With the growth in area of cultivated forage plants, mainly with seeds of Brachiaria brizantha (Hochst. Ex A. Rich) Stapf., the increment in the incidence of pathogens has become a problem of growing importance (EUCLIDES et al., 2010; VECHIATO; APARECIDO, 2008). Among the main factors responsible for the occurrence of pathogens in seeds are those of the absence of sanitary standards and the scarceness of information concerning the sanity of seeds produced and commercialized in Brazil (MALLMANN et al., 2013).

Information concerning seed sanity is demanded in Brazil only when the seeds are to be exported (BRASIL, 2008; MARCHI et al., 2010a; VECHIATO; APARECIDO, 2008). Brachiaria sp. seeds infected with Claviceps sp., for instance, represent a sanitary barrier for commercial transactions with Guatemala, Mexico, and Panama (MARCHI et al., 2010a). The presence of pathogens in the seeds may reduce seed germination, vigor and yield, considering the chances of several pathogens being transported by the seeds (SBALCHEIRO; ROVERI; BARBOSA, 2014).

Studies concerning the incidence of fungi in seeds of $B$. brizantha showed the presence of Cladosporium sp., Curvularia sp., Fusarium sp., and Phoma sp in B. brizantha cv. 'Marandu' and 'Xaraés' cultivars seeds produced in the states of Mato Grosso, Goiás, and Mato Grosso do Sul (GUIMARÃES et al., 2006; MALLMANN et al., 2013). This type of investigation allows to identify the geographical distribution of the pathogen helping in the process of choosing pathogen-free areas for the production of seeds (AZEVEDO; FARIA, 1982).

Forage seeds infection with pathogens takes place mainly in the soil, where saprophytic microorganisms are found such as Fusarium sp., Helminthosporium sp., Phoma sp., Aspergillus sp., Chaetomium sp., Nigrospora sp., among others. These organisms show rapid vegetative growth and sporulation and this causes healthy seeds to be easily infected during transport, processing and storage (AZEVEDO; FARIA, 1982; FAVORETO et al., 2011).

So, the identification of appropriate production areas is important for the logistic and the 
quality control programs of seed companies to select farmers to whom entrust the production of seeds so to avoid the introduction of pathogens in exempt areas (CARVALHO; NAKAGAWA, 2012).

Thus, the present project aimed to identify the fungi present in commercial seed lots of $B$. brizantha cv. Marandu and Xaraés of different production loci.

\section{MATERIAL AND METHODS}

Twenty commercial seed lots were evaluated, ten of the 'Marandu' and another 10 of the 'Xaraés' cultivars of $B$. brizantha. The lots were produced and harvested in the crop year of $2013 / 2014$ in the following list of municipalities Table 1.

The seeds came from the field of production for the laboratory soon after harvest (There was no storage). Harvesting was performed by harvesting machine by soil sweeping. In the reports made by the technical responsible of these fields of production there were no reports of diseases or recommendations of phytosanitary treatment for the control of fungi.

Table 1. Characteristics of the producing loci of seed lots of B. brizantha cv. Marandu and Xaraés (Source : Climate-data. Org., 2015). Jaboticabal, state of São Paulo, Brazil.

\begin{tabular}{|c|c|c|c|c|c|c|c|c|}
\hline B. brizantha & Lots & Origin & $\begin{array}{l}\text { Latitude } \\
\text { (S) }\end{array}$ & $\begin{array}{l}\text { Longitude } \\
\text { (W) }\end{array}$ & $\begin{array}{l}\text { Altitude } \\
(\mathrm{m})\end{array}$ & Climate $^{1}$ & $\begin{array}{c}\text { Temperature } \\
\left({ }^{\circ} \mathrm{C}\right)\end{array}$ & $\begin{array}{c}\text { Precipitation } \\
(\mathrm{mm})\end{array}$ \\
\hline cv. & & & & & 831 & Aw & 22,5 & 1,627 \\
\hline \multirow[t]{7}{*}{ Marandú } & 1 & Chapadão do Ceú - GO & $18^{\circ} 23^{\prime} 34^{\prime}$, & $52^{\circ} 39^{\prime} 57^{\prime}$, & & & & \\
\hline & 2 & Quirinópolis - GO & $20^{\circ} 41^{\prime} 08^{\prime \prime}$ & $50^{\circ} 33^{\prime} 17^{\prime}$, & 480 & Aw & 23,5 & 1,324 \\
\hline & 3 & Uruana de Minas - MG & $16^{\circ} 03^{\prime} 51^{\prime}$, & $46^{\circ} 15^{\prime} 15^{\prime}$, & 550 & Aw & 23,4 & 1,204 \\
\hline & 4 & Luís Eduardo Magalhães - BA & $12^{\circ} 05^{\prime} 58^{\prime \prime}$ & $45^{\circ} 47^{\prime} 54^{\prime}$, & 765 & Aw & 24,2 & 1,511 \\
\hline & 5 and $6^{*}$ & Chapada Gaúcha - MG & $15^{\circ} 28^{\prime} 06^{\prime \prime}$ & $45^{\circ} 25^{\prime} 06^{\prime \prime}$ & 871 & Aw & 22,3 & 1,217 \\
\hline & 7 and $8^{*}$ & Tupaciguara - MG & $18^{\circ} 35^{\prime} 32^{\prime}$, & $48^{\circ} 42^{\prime} 18^{\prime \prime}$ & 896 & Aw & 21,8 & 1,409 \\
\hline & 9 and $10^{*}$ & Monte Alegre de Minas - MG & $18^{\circ} 52^{\prime} 13^{\prime \prime}$ & $48^{\circ} 52^{\prime} 31^{\prime \prime}$ & 732 & Aw & 22,4 & 1,313 \\
\hline \multirow[t]{7}{*}{ cv. Xaraés } & 1 & Rosário do Oeste - MT & $14^{\circ} 50^{\prime} 10^{\prime}$ & $56^{\circ} 25^{\prime} 39^{\prime \prime}$ & 191 & Aw & 25,0 & 1,406 \\
\hline & 2 & Santo Anastácio - SP & $21^{\circ} 59^{\prime} 11^{\prime \prime}$ & $51^{\circ} 39^{\prime} 40^{\prime \prime}$ & 449 & Cfa & 21,7 & 1,162 \\
\hline & 3 and $4^{*}$ & Chapada Gaúcha - MG & $15^{\circ} 28^{\prime} 06^{\prime \prime}$ & $45^{\circ} 25^{\prime} 06^{\prime \prime}$ & 871 & Aw & 22,3 & 1,217 \\
\hline & & & $16^{\circ}$ & & 563 & Aw & 23,5 & 1,275 \\
\hline & 5 and $6^{*}$ & Unaí - MG & $21^{\prime} 27^{\prime}$ & $46^{\circ} 54^{\prime} 22^{\prime \prime}$ & & & & \\
\hline & 7 and $8^{*}$ & Paraíso das Águas- MS & $18^{\circ} 56^{\prime} 36^{\prime}$ & $52^{\circ} 59^{\prime} 52^{\prime}$ & 606 & Aw & 23,6 & 1,549 \\
\hline & 9 and $10^{*}$ & Primavera do Leste - MT & $15^{\circ} 33^{\prime} 32^{\prime \prime}$ & $54^{\circ} 17^{\prime} 46^{\prime}$, & 661 & Aw & 22,0 & 1,784 \\
\hline
\end{tabular}

${ }^{1}$ Classification according to Koppen and Geigher (1928). http:// pt. climate-data. Org/country/114/Aw (savannah tropical climate with a dry Winter season) with a mean temperature above $18{ }^{\circ} \mathrm{C}$ at any month of the year. The winter season is dry with a mean precipitation below $60 \mathrm{~mm}$ in at least one of the months of this season. Cfa (temperate humid climate with a hot summer) with a mean temperature of the coolest month between 3 and $18{ }^{\circ} \mathrm{C}$. There is no dry season during the year with a precipitation above $60 \mathrm{~mm}$ during the driest month of the year. Summer is hot - the mean temperature of the hottest month is above $22^{\circ} \mathrm{C}$.

${ }^{*}$ These lots were harvested from fields belonging to different farmers of the same municipality.

Seed water content and germination were evaluated in the Seed Analysis Laboratory, a unit of the Department of Plant Production of the College of Agrarian Sciences and Veterinary of the University of the State of São Paulo (UNESP) on its campus of Jaboticabal, state of São Paulo, and the Phytopathology Laboratory of the Department of Plant Production and Environmental Sciences of the Agrarian Sciences Center of the National University of Paraíba, Areia, state of Paraíba, Brazil.

Water content of seeds - this variable was determined by the oven method at $105 \pm 3{ }^{\circ} \mathrm{C}$ for a period of 24 hours (BRASIL, 2009).

Germination test - eight replications of 50 seeds each were taken from each lot and sown between two filter paper sheets which were imbibed in an amount of water equivalent to 2.5 times the paper weight. Then they were placed inside transparent plastic boxes $(11.0 \times 11.0 \times 3.5 \mathrm{~cm})$ which were put inside a germinator kept between the temperatures of 20 and $35^{\circ} \mathrm{C}$. Normal seedlings were those whose plumule had outgrown the coleoptile and the primary root was at least $0.5 \mathrm{~cm}$ long. Counts were made at week intervals up to the 21rst day after sowing (Adaptado de BRASIL, 2009).

Sanity analysis - the evaluation of the seeds microorganisms was accomplished by the Blottertest. Eight 25 seed samples of each lot were sown on two sterile sheets of filter paper which were wet with distilled and sterilized water inside transparent plastic boxes $(11.0 \times 11.0 \times 3.0 \mathrm{~cm}) \mathrm{kept}$ at $20^{\circ} \mathrm{C}$ for seven days (MARCHI et al., 2010b ). Following the incubation period, the seed mycoflora was 
identified with the help of a stereoscopic and optical light microscope. The identification key (BARNETT; HUNTER, 1998) was used to identify the fungi at the genus level. Following identification, the incidence of the fungus in the seed was determined and the result expressed in percentage.

Only the incidence data (\%) were transformed into $\sqrt{x}+0.5$. All the data were submitted to the analysis of variance by means of the $\mathrm{F}$ test and the means compared by the Tukey test at the level of 5\% of probability. Pearson's coefficient of correlation between the values of incidence of each fungus was determined and the interpretation of the correlations followed the following described by Figueiredo-Filho and SilvaJúnior (2009): $\quad r=$ between 0.10 and 0.30 (weak correlation); $r=$ between 0.40 and 0.60 (moderate); $r$ $=$ between 0.70 and 1.0 (strong).

\section{RESULTS AND DISCUSSION}

Seed water content was verified to be between 9.0 and $10.0 \%$, for the 'Xaraés grass' seeds and between 10.0 and $12.0 \%$ for the 'Marandu' grass seeds. These values are considered ideal for seed storage - according to Previero et al.(1999), seed water contents above $13 \%$, depending on the type of package and of the environmental temperature, may favor increments in seed respiratory activity, the concentration of carbon gas, the temperature and the incidence of pathogens in the seeds.

As to germination, none of the lots used in this experiment germinated less than $60 \%$ (Tables 2 and 3), i.e., all lots were within the required standards for forage grass seeds (BRASIL, 2008).

Table 2. Germination (G) and incidence of fungi in Marandu grass seeds (Brachiaria brizantha cv. Marandu) produced in different regions. Jaboticabal, state of São Paulo, 2015.

\begin{tabular}{ccccccccc}
\hline & & \multicolumn{7}{c}{ Incidence of Fungi (\%) } \\
\cline { 3 - 9 } & $\mathrm{G}(\%)$ & $\begin{array}{c}\text { Helminthosporium } \\
\text { sp }\end{array}$ & $\begin{array}{c}\text { Fusarium } \\
\text { sp. }\end{array}$ & $\begin{array}{c}\text { Aspergillus } \\
\text { sp. }\end{array}$ & $\begin{array}{c}\text { Curvularia } \\
\text { sp. }\end{array}$ & $\begin{array}{c}\text { Chaetomium } \\
\text { sp. }\end{array}$ & $\begin{array}{c}\text { Phoma } \\
\text { sp. }\end{array}$ & $\begin{array}{c}\text { Pyricularia } \\
\text { grisea }\end{array}$ \\
\hline 1 & $74 \mathrm{a}$ & $40 \mathrm{a}$ & $19 \mathrm{ab}$ & $5 \mathrm{a}$ & $0 \mathrm{c}$ & $0 \mathrm{~b}$ & $0 \mathrm{~b}$ & $0 \mathrm{~b}$ \\
2 & $70 \mathrm{ab}$ & $20 \mathrm{c}$ & $19 \mathrm{abc}$ & $5 \mathrm{a}$ & $0 \mathrm{c}$ & $0 \mathrm{~b}$ & $20 \mathrm{a}$ & $0 \mathrm{~b}$ \\
3 & $71 \mathrm{ab}$ & $13 \mathrm{c}$ & $8 \mathrm{~cd}$ & $6 \mathrm{a}$ & $8 \mathrm{ab}$ & $0 \mathrm{~b}$ & $0 \mathrm{~b}$ & $0 \mathrm{~b}$ \\
4 & $60 \mathrm{c}$ & $36 \mathrm{ab}$ & $4 \mathrm{e}$ & $0 \mathrm{~b}$ & $14 \mathrm{a}$ & $0 \mathrm{~b}$ & $0 \mathrm{~b}$ & $6 \mathrm{a}$ \\
5 & $66 \mathrm{bc}$ & $21 \mathrm{bc}$ & $26 \mathrm{a}$ & $0 \mathrm{~b}$ & $0 \mathrm{c}$ & $10 \mathrm{a}$ & $0 \mathrm{~b}$ & $0 \mathrm{~b}$ \\
6 & $69 \mathrm{ab}$ & $14 \mathrm{c}$ & $2 \mathrm{e}$ & $0 \mathrm{~b}$ & $8 \mathrm{ab}$ & $5 \mathrm{a}$ & $0 \mathrm{~b}$ & $0 \mathrm{~b}$ \\
7 & $69 \mathrm{ab}$ & $16 \mathrm{c}$ & $5 \mathrm{e}$ & $0 \mathrm{~b}$ & $0 \mathrm{c}$ & $10 \mathrm{a}$ & $0 \mathrm{~b}$ & $0 \mathrm{~b}$ \\
8 & $60 \mathrm{c}$ & $19 \mathrm{c}$ & $20 \mathrm{abc}$ & $6 \mathrm{a}$ & $0 \mathrm{c}$ & $0 \mathrm{~b}$ & $19 \mathrm{a}$ & $0 \mathrm{~b}$ \\
9 & $60 \mathrm{c}$ & $11 \mathrm{c}$ & $8 \mathrm{~cd}$ & $0 \mathrm{~b}$ & $6 \mathrm{~b}$ & $0 \mathrm{~b}$ & $0 \mathrm{~b}$ & $0 \mathrm{~b}$ \\
10 & $70 \mathrm{ab}$ & $15 \mathrm{c}$ & $8 \mathrm{~d}$ & $5 \mathrm{a}$ & $4 \mathrm{~b}$ & $0 \mathrm{~b}$ & $0 \mathrm{~b}$ & $8 \mathrm{a}$ \\
\hline C.V $\%$ & 4,90 & 3,34 & 2,95 & 1,94 & 1,36 & 1,12 & 1,05 & 1,14 \\
\hline
\end{tabular}

Means, in the same column, followed by the same letter, are not significantly different, according to the Tukey test $(\mathrm{p} \leq 0.05)$.

*Production loci - lot 1: county of Chapadão do Céu, state of Goiás; lot 2: county of Quirinópolis, state of Goiás; lot 3: county of Uruana de Minas, state of Minas Gerais; lot 4: county of Luis Eduardo Magalhães, state of Bahia; lots 5 and 6: county of Chapada Gaúcha, state of Minas Gerais; lots 7 and 8: Tupaciguara, state of Minas Gerais; lots 9 and 10: Monte Alegre de Minas, state of Minas Gerais.

Table 3. Germination $(\mathrm{G})$ and incidence of fungi in Marandu grass seeds (Brachiaria brizantha cv. 'Xaraés') produced in different regions. Jaboticabal, state of São Paulo, 2015.

\begin{tabular}{ccccccccc}
\hline & & \multicolumn{7}{c}{ Incidence of Fungi (\%) } \\
\cline { 3 - 8 } Lots* & $\mathrm{G}(\%)$ & $\begin{array}{c}\text { Fusarium } \\
\text { sp }\end{array}$ & $\begin{array}{c}\text { Chaetomium } \\
\text { sp }\end{array}$ & $\begin{array}{c}\text { Curvularia } \\
\text { sp. }\end{array}$ & $\begin{array}{c}\text { Nigrospora } \\
\text { sp }\end{array}$ & $\begin{array}{c}\text { Helmithosporium } \\
\text { sp. }\end{array}$ & $\begin{array}{c}\text { Colletotrichum } \\
\text { sp. }\end{array}$ & $\begin{array}{c}\text { Aspergillus } \\
\text { sp. }\end{array}$ \\
\hline 1 & $71 \mathrm{bc}$ & $12 \mathrm{~cd}$ & $13 \mathrm{ab}$ & $6 \mathrm{~b}$ & $0 \mathrm{~d}$ & $0 \mathrm{e}$ & $0 \mathrm{~b}$ & $0 \mathrm{~b}$ \\
2 & $67 \mathrm{~cd}$ & $12 \mathrm{~cd}$ & $0 \mathrm{c}$ & $13 \mathrm{ab}$ & $0 \mathrm{~d}$ & $41 \mathrm{~b}$ & $0 \mathrm{~b}$ & $0 \mathrm{~b}$ \\
3 & $83 \mathrm{a}$ & $4 \mathrm{ef}$ & $18 \mathrm{a}$ & $4 \mathrm{bc}$ & $7 \mathrm{~b}$ & $9 \mathrm{~d}$ & $0 \mathrm{~b}$ & $0 \mathrm{~b}$ \\
4 & $71 \mathrm{bc}$ & $0 \mathrm{f}$ & $22 \mathrm{a}$ & $14 \mathrm{a}$ & $15 \mathrm{a}$ & $14 \mathrm{c}$ & $0 \mathrm{~b}$ & $0 \mathrm{~b}$ \\
5 & $78 \mathrm{ab}$ & $20 \mathrm{abc}$ & $6 \mathrm{~b}$ & $0 \mathrm{c}$ & $9 \mathrm{~b}$ & $0 \mathrm{e}$ & $0 \mathrm{~b}$ & $0 \mathrm{~b}$ \\
6 & $60 \mathrm{~d}$ & $20 \mathrm{abc}$ & $14 \mathrm{a}$ & $11 \mathrm{ab}$ & $0 \mathrm{~d}$ & $55 \mathrm{a}$ & $0 \mathrm{~b}$ & $0 \mathrm{~b}$
\end{tabular}


Sanitary quality...

MARTINS, C. C. et al

\begin{tabular}{ccccccccc}
7 & $81 \mathrm{a}$ & $7 \mathrm{de}$ & $14 \mathrm{a}$ & $0 \mathrm{c}$ & $0 \mathrm{~d}$ & $0 \mathrm{e}$ & $9 \mathrm{a}$ & $0 \mathrm{~b}$ \\
8 & $60 \mathrm{~d}$ & $27 \mathrm{a}$ & $19 \mathrm{a}$ & $0 \mathrm{c}$ & $0 \mathrm{~d}$ & $0 \mathrm{e}$ & $0 \mathrm{a}$ & $0 \mathrm{~b}$ \\
9 & $60 \mathrm{~d}$ & $20 \mathrm{abc}$ & $13 \mathrm{ab}$ & $10 \mathrm{ab}$ & $3 \mathrm{c}$ & $0 \mathrm{e}$ & $5 \mathrm{a}$ \\
10 & $60 \mathrm{~d}$ & $25 \mathrm{ab}$ & $15 \mathrm{a}$ & $0 \mathrm{c}$ & $0 \mathrm{~d}$ & $0 \mathrm{e}$ & $0 \mathrm{~b}$ & $10 \mathrm{a}$ \\
\hline C.V \% & 4,74 & 2,88 & 2,40 & 1,56 & 1,09 & 1,25 & 1,03 & 1,02 \\
\hline
\end{tabular}

Means, in the same column, followed by the same letter are not significantly different according to the Tukey test $(\mathrm{p} \leq 0.05)$.

*Production loci - lot 1: county of Rosário do Oeste, state of Mato Grosso; lot 2: county of Santo Anastácio, state of São Paulo; lots 3 and 4: county of Chapada Gaucha, state of Minas Gerais; lots 5 and 6: county of Unaí, state of Minas Gerais; lots 7 and 8: county of Paraíso das Águas, state of Mato Grosso do Sul; lots 9 and 10: county of Primavera do Leste, state of Mato Grosso.

There was significant difference $(\mathrm{p}<0.05)$ between seed lots for germination and incidence of fungi. The lowest germination values $(60 \%)$ were verified for the 'Marandu' grass seeds produced in the county of Luis Eduardo Magalhães, state of Bahia (lot 4), another one produced in the county of Tupaciguara, state of Minas Gerais (lot 8), and one of the two lots produced in the county of Monte Alegre de Minas, state of Minas Gerais (lot 9) (Table 2).

Analyzing the 'Xaraés' grass seeds, it is seen that the lowest germination was detected in one of the two lots produced in the county of Unai, state of Minas Gerais, another one from the county of
Paraíso das Águas, state of Mato Grosso do Sul (lot 8) and the two lots from Primavera do Leste, a county of the state of Mato Grosso (lots 9 and 10) (Table 3). Thus, the lower germination performance would not be associated only with the climatic characteristics of the region of production but also with the inherent characteristics of the field where production took place. The occurrence of rainfall near the harvest season may have caused the low germination of some lots $(60 \%)$.

As shown in Table 4, no correlation was found between germination and incidence of fungi in seeds of the 'Marandu' cultivar.

Table 4. Pearson's coefficient of correlation (r) between results of the standard germination test and the incidence of fungi in seeds of ten commercial lots of 'Marandu' grass and 'Xaraés' grass produced in different loci. Jaboticabal, state of São Paulo, Brazil. 2015.

\begin{tabular}{ccc}
\hline Germination X Fungi & Marandu grass & Xaraés grass \\
\hline Aspergillus sp. & 0,298 & $-0,487$ \\
Chaetomium sp. & 0,035 & $-0,028$ \\
\hline Curvularia sp. & $-0,205$ & $-0,202$ \\
Fusarium sp. & 0,005 & $-0,517$ \\
Helminthosporium sp. & 0,145 & $-0,149$ \\
\hline Phoma sp. & 0,192 & - \\
Pyricularia grisea & $-0,030$ & - \\
Colletotrichum sp. & - & 0,085 \\
Nigrospora sp. & - & 0,427 \\
\hline
\end{tabular}

The germination of the 'Xaraés' cultivar seeds was reduced by the incidence of Aspergillus sp., Fusarium sp., and Nigrospora sp. although the coefficient of correlation values were between 0.4 and 0.6. According Figueiredo-Filho and SilvaJúnior (2009) Coefficient of correlation values between 0.4 and 0.6 are considered relevant in studies that studied the relationship between the incidence of fungi in seeds and germination (Table 4).

As to the mycoflora, in seeds of the 'Marandu' grass, some fungi, such as Helminthosporium sp. and Fusarium sp., were found to occur in a generalized way since they were found in all lots of all production loci (Table 2). According to a report by Favoreto et al. (2011),
Helminthosporium sp. fungi were found in every signalgrass seed lots they examined.

The seeds of lots 6 and 7 (Table 2), produced in 'Chapada Gaúcha' and in 'Tupaciguara', both counties of the state of Minas Gerais, presented the lowest levels of infection with Fusarium sp. The occurrence of Fusarium sp., in association with poor management, has contributed to the death of several 'Marandu' grass pasture areas of the Amazon region (VERZIGNASSI et al., 2012) as well as pastures in the states of Pará, Acre, Maranhão, and Rondonia (DUARTE et al., 2007).

The occurrence of Fusarium sp. in seed lots is worrying since this fungus is capable of causing the death of seeds and of plants of various species of economic importance (FONSECA-NETO et al., 
2016; RAMOS et al., 2014; SALGADO-NETO et al., 2016). Once an area is contaminated with this fungus, its eradication is very difficult - it may remain viable for years in the soil (FONSECANETO et al., 2016; SALGADO-NETO et al., 2016). Its presence in a seed lot makes it unviable even when it is present in low levels, due to its high infection potential (RAMOS et al., 2014).

Another fungi such as Aspergillus sp. and Curvularia sp. were detected in seed lots of the 'Marandu' grass produced in half of the producing loci: 'Chapadão do Céu' and 'Quirinópolis', both counties of the state of Goiás, 'Uruana de Minas', 'Tupaciguara', 'Monte Alegre de Minas', and 'Chapada Gaúcha', all counties of the state of Minas Gerais, and 'Luis Eduardo Magalhães', a county of the state of Bahia. On the other hand, fungi such as Phoma sp. and Chaetomium sp. were found in seeds of only two producing loci (Table 2).

Notwithstanding being considered a secondary fungus, Aspergillus sp. is an important one for grass seeds, since it causes seed rotting and it is related to high water contents and inadequate physiological conditions of the seed and, due to its rapid multiplication, it may contaminate and compromise all the seed lot during the storage period (BORÉM et al., 2006; HENNING et al., 2011).

The maximum incidence of Fusarium sp. Were detected infection levels above $19 \%$ in 'Marandu' grass seed lots which had been produced in 'Chapadão do Céu' (lot 1), 'Quirinópolis' (lot 2), both counties of the state of Goiás and 'Chapada Gaúcha' (lot 5) and 'Tupaciguara' (lot 8), counties of the state of Minas Gerais. When sanitary reports corresponding to the production of brachiaria seeds in the states of Minas Gerais and Goiás, Barros and Juliatti (2012) in the period between 2001 and 2008, are analyzed, it is verified that 78 cases of Fusarium sp. and 59 of Phoma sp. were reported, with mean incidence levels of 22 and 18\%, respectively.

If the intention is to export brachiaria seeds, the infection with Phoma sp. is a serious barrier to the entrance of that seed in countries such as Mexico and Colombia (VECHIATO; APARECIDO, 2008). This fungus can to promote severe damage in emergence and lead to the death of brachiaria seedlings (LASCA et al., 2004).

The observed differences in levels of incidence of fungi shown by seeds of different production loci are due to the practices adopted during and after harvest, the relative humidity of the air, the lack of sanitary standards and also the lack of registered products for the chemical treatment of forage seeds (GUIMARÃES et al., 2006; MARCHI et al., 2010a).

The maximum incidence levels of Helminthosporium sp. were observed in brachiaria seeds produced in 'Chapadão do Céu' (lot 1), a county of the state of Goiás, and in 'Luis Eduardo Magalhães' (lot 4), a county of the state of Bahia which were, respectively, of 40 and $36 \%$. The occurrence of Helminthosporium sp. in 'Marandu' grass seeds produced in the counties of 'Aparecida do Rio Doce' and 'Quirinópolis' in the state of Goiás and in the county of 'São Desidério', in the state of Bahia, was reported by Santos et al. (2014) although with values lower than $4 \%$. Seed infection by Helminthosporium sp. takes place through the contact of seed with the soil and plant residues. This fact contributes to the increment of fungi inoculum which survives in plant residues in seed producing regions (FARIAS et al., 2002; FAVORETO et al., 2011).

In the other lots $(2,3,5,6,7,8,9$, and 10), though, lower levels (values between 11 and 21\%) of infection with Helminthosporium sp. were observed (Table 2) this being believed to be due to the fact that the incidence of the pathogen may be related to the characteristics of the field where the seeds were produced as well as the soil inoculum potential (CARVALHO; NAKAGAWA, 2012), i.e., in a way similar to that previously mentioned for Fusarium sp.

The fungus Aspergillus sp. was verified to occur only in half of the 'Marandu' seed lots, i.e., those produced in the counties of 'Chapadão do Céu', 'Quirinópolis', of the state of Goiás, and 'Tupaciguara', 'Uruana de Minas' and 'Monte Alegre de Minas', of the state of Minas Gerais (lots $1,2,3,8$, and 10) with infection values between 5 and $6 \%$. Curvularia sp., in infection levels between 4 and $14 \%$, was observed to occur in lots produced in 'Uruana de Minas' (lot 3), 'Chapada Gaúcha' (10t 6), and 'Monte Alegre de Minas' (lots 9 and 10), counties of the state of Minas Gerais and in 'Luis Eduardo Magalhães' (lot 4), a county of the state of Bahia.

Pathogens of the genus Chaetomium were found in seeds of the two lots from 'Chapada Gaúcha', state of Minas Gerais (lots 5and 6) and in one of the lots from 'Tupaciguara', state of Minas Gerais (lot 7) in infection levels between 5 and 10\%. Phoma sp. was found in seeds from 'Quirinópolis', state of Goiás, and from 'Tupaciguara', state of Minas Gerais (lots 2 and 8) in percentages of 20 and $19 \%$, respectively. P. grisea was detected in seeds from 'Luis Eduardo Magalhães', state of Bahia, and from 'Monte Alegre de Minas', state of Minas 
Gerais (lots 4 and 10) in infection levels between 8 and $6 \%$. This may be considered the first report of the occurrence of $P$. grisea in seeds of tropical forage grasses produced in the Southeast and Northeast regions of Brazil.

The only report mentioning the occurrence of this pathogen in samples of seeds of 'Marandu' grass in Brazil refers to a lot produced in Rondon do Pará, a county of the state of Pará, of the Northern region of Brazil (VERZIGNASSI et al., 2012) and this fact is thought to be an indication that this pathogen is being disseminated throughout the Brazilian territory.

In the states of Pará and Maranhão, reports have been written informing the death of 80 to $90 \%$ of 'Marandu' grass plants due to the incidence of $P$. grisea. The symptoms of the disease when transmitted from the seeds to the plants, consist of brown-reddish spots in the leaf surface which eventually cause the death of the plant (VERZIGNASSI et al., 2012).

Pyricularia grisea, the causal agent of rice blast, has a series of host plants. In Brazil, rice, wheat, triticale, and rye are the crops which undergo expressive reductions of productivity due to attacks by that pathogen - this pathogen interferes directly in the photosynthetic process (GALBIERI; URASHIMA, 2008). Beyond those crops, this pathogen is also capable of infecting several forage grasses and weeds, such as Brachiaria decumbens, $B$. plantaginea, Lollium multiflorum, Avena strigosa, Echinochloa cruz-galli, among others (GALBIERI; URASHIMA, 2008; MARCHI et al., 2005). Thus, countries such as Mexico and Colombia have raised sanitary restrictions to the importation of tropical forage grass seeds contaminated with $P$. grisea (VECHIATO; APARECIDO, 2008).

In the 'Xaraés' grass seed lots, Fusarium sp. and Chaetomium sp. were verified to occur in a generalized way since they were found in lots from nine of the ten producing loci; only the seeds of lot 4 (Chapada Gaúcha', state of Minas Gerais) were not infected with Fusarium sp. and those from Santo Anastácio, state of São Paulo (lot 2) by Chaetomium sp. (Table 3). This generalized occurrence of Fusarium sp. in all lots had also been detected in the seeds of the 'Marandu' grass (Table 2).

The high incidence of fungi of rapid and aggressive growth such as Fusarium sp. in 'Marandu' grass seed lots is worrying since they can cause the death of the seeds before they germinate (MARCHI et al., 2010b), although in the present research this fact was not verified, as shown by the correlation data (Table 4). Differently, the behavior of the seeds of the 'Xaraés' cultivar was of losses in germination caused by the presence of Fusarium sp., Aspergillus sp. and Nigrospora sp. with a moderate correlation coefficient (between 0.4 and $0.6)$.

The infection of forage seeds by Fusarium sp., Aspergillus sp., and Nigrospora sp. is a problem to the physiological quality since these fungi may cause deterioration, reducing germination and vigor (MARCHI et al., 2006; MARCHI et al., 2010a). According to Farias et al. (2002), the presence of storage fungi such as Aspergillus sp. and Nigrospora sp. in the seeds is associated with management procedures during and after harvest as well as to air relative humidity during storage.

The maximum incidence of Fusarium sp. was found in lots of 'Xaraés' grass seeds produced in Unaí, a county of the state of Minas Gerais (lots 5 and 6), in Paraiso das Águas, a county of the state of Mato Grosso do Sul (lot 8), and in Primavera do Leste, a county of the state of Mato Grosso (lots 9 and 10), with values above $20 \%$ (Table 3 ). This is an indication of the high importance of seeds in transmitting plant pathogens of high risk from one region to another.

With the exception of seeds of lots 2 and 5 (which were produced in Santo Anastácio, state of São Paulo, and Unaí, state of Minas Gerais, respectively) the other lots all showed maximum levels of infection, above $13 \%$. Fungi of the genera Curvularia sp., Helminthosporium sp., and Nigrospora sp. were detected in approximately half of the producing loci.

The genus Curvularia sp. was found in lots produced in Rosário do Oeste, state of Mato Grosso, Santo Anastácio, state of São Paulo, Chapada Gaucha, state of Minas Gerais, Unaí, state of Minas Gerais, and Primavera do Leste, state of Mato Grosso (lots 1, 2, 3, 4, 6, and 9) in values between 4 and $14 \%$. Nigrospora sp. was verified in lots of Xaraés grass seeds produced in Chapada Gaúcha, state of Minas Gerais, Unaí, state of Minas Gerais, and Primavera do Leste, state of Mato Grosso (lots $3,4,5$, and 9) in incidence values between 3 and $15 \%$.

Seeds infected with Helminthosporium sp. were found in lots produced in Santo Anastácio, state of São Paulo, Chapada Gaucha, state of Minas Gerais, and Unaí, also state of Minas Gerais (lots 2, 3, 4, and 6) in values between 9 and 55\% (Table 3). The high incidence of Helminthosporium sp. detected in Xaraés grass seeds produced in Unai, state of Minas Gerais, and Santo Anastácio, state of São Paulo, with values above $41 \%$, are similar to those $40 \%$ shown by seeds of Marandu grass from 
Chapadão do Céu, state of Goiás (Table 2). The occurrence of Helminthosporium sp. in seeds of Xaraés grass was reported by Favoreto et al. (2011), although the mean incidence was of $59 \%$.

The other fungi detected in the seeds of Xaraés grass were Colletotrichum sp. and Aspergillus sp. although the occurrence was in restrict areas since they were found in two seed lots from the same counties (Table 3). Colletotrichum sp. was detected in seeds from Paraíso das Águas, state of Minas Gerais (lots 7 and 8) in percentages of 9 and $10 \%$ and Aspergillus sp. in seeds produced in Primavera do Leste, state of Mato Grosso (lots 9 and 10) in values between 5 and $10 \%$.

These - counties where high annual rain precipitations are common - are those where most of the Xaraés grass seeds are produced (Table 1). In Paraíso das Águas, state of Mato Grosso do Sul, and Primavera do Leste, state of Mato Grosso, mean yearly precipitation indexes are of 1,594 and 1,784 $\mathrm{mm}$, respectively. These climatic conditions in association the inoculum potential of these areas seem to have favored the dissemination of Colletotrichum sp. and Aspergillus sp. in Xaraés grass seeds.

The high incidence of Colletrotrichum sp. in some regions of Latin America is a factor limiting the production of grass seeds. This fungus was detected in Xaraés grass seeds imported from Paraguay in levels of $19 \%$ (BORRELL; AGUILERA; AQUINO, 2013).

The incidence of potentially pathogenic fungi as Curvularia sp., Fusarium sp., and Phoma sp., and Secondary fungi or of storage as Aspergillus

sp., Chaetomium sp., Colletotrichum sp, Helminthosporium sp., and Nigrospora sp., in some lots of Marandu and Xaraés is an indication that those are the commonest fungi in the seeds of those cultivars (Tables 2 and 3). Similar results were reported by Favoreto et al. (2011), Marchi et al. (2010b) and Santos et al. (2014).

These results emphasize the potential risks these fungi represent for the exportation of Marandu and Xaraés grass seeds considering the sanitary demands imposed by importing countries.

\section{CONCLUSIONS}

In the seeds of both grasses, the incidences of Aspergillus sp., Chaetomium sp., Curvularia sp., Fusarium sp, and Helminthosporium fungi were verified.

The seeds of Marandu grass were the only ones infected with Phoma sp. and Pyricularia grisea and those of Xaraés grass with Colletotrichum sp. and Nigrospora sp.

The incidence of Fusarium sp., Aspergillus sp., and Nigrospora sp. reduces Xaraés grass seed germination but does not interfere in the germination of Marandu seeds.

The occurrence of the fungus Pyricularia grisea in seeds of tropical forage grass seeds is for the first time reported in the Southeast and Northeast regions of Brazil.

RESUMO: A incidência de fungos em sementes depende das condições de sanidade e climáticas dos locais de procedência. Assim, o objetivo do presente estudo foi identificar os fungos presentes em lotes comerciais de sementes de Brachiaria brizantha cv. Marandú e Xaraés coletadas em diferentes áreas. Sementes de dez lotes de cada cultivar produzidas nos Estados de Mato Grosso do Sul, Mato Grosso, Goiás, Minas Gerais, São Paulo e Bahia foram avaliados quanto ao teor de água, germinação e a sanidade. Nas sementes de ambos os capins verificou-se a incidência de Aspergillus sp., Chaetomium sp., Curvularia sp., Fusarium sp. e Helminthosporium sp. com maior importância para Chaetomium sp. e Fusarium sp. As sementes de capim-marandú foram as únicas com presença de Phoma sp. e Pyricularia grisea e de capim-xaraés com Colletotrichum sp. e Nigrospora sp. A incidência de Fusarium sp., Aspergillus sp. e Nigrospora sp. reduz a germinação de sementes de capim-xaraés e a ocorrência de fungos não interfere na germinação de capim-marandú. O fungo Pyricularia grisea é relatado pela primeira vez em sementes de gramíneas forrageiras tropicais produzidas no Sudeste e Nordeste do Brasil.

PALAVRAS-CHAVE: Germinação. Sementes forrageiras. Gramíneas forrageiras. Locais de produção.

\section{REFERENCES}

AZEVEDO, J. T.; FARIA, L. A. L. Produção de sementes. Informe Agropecuário, Belo Horizonte, v. 8, n. 9 , p. 28-31, 1982. 
BARNETT, H. L.; HUNTER, B. B. Illustrated genera of imperfect fungi. 4 ed. The Americam Phythological Society. Saint Paul, 1998, 218 p.

BARROS, F. C.; JULIATTI, F. C. Levantamento de fungos em amostras recebidas no laboratório de micologia e proteção de plantas da Universidade Federal de Uberlândia, no período 2001-2008. Bioscience Journal, Uberlândia, v. 28, n. 1, p. 77-86, Jan/Fev. 2012.

BORÉM, F. M.; RESENDE, O.; MACHADO, J. C.; FONTENELLE, I. M. R.; SOUZA, F. F. de. Controle de fungos presentes no ar e em sementes de feijão durante armazenamento. Revista Brasileira de Engenharia Agrícola e Ambiental, Campina Grande, v. 10, n. 3, p. 651-659, 2006. https://doi.org/10.1590/S141543662006000300017

BORRELL, C. C. M.; AGUILERA, L. A.; AQUINO, A. Evaluación fitosanitaria de semillas en diez especies forrajeras tropicales. Investigación Agraria, San Lorenzo, v. 7, n. 2, p. 5-9, 2013.

BRASIL. Ministério da Agricultura, Pecuária e do Abastecimento. Instrução Normativa n ${ }^{\circ}$ 30, de 21 de maio de 2008. Diário Oficial da União, Brasília, DF, 23 maio 2008. Seção 1, p. 45.

BRASIL. Ministério da agricultura, pecuária e abastecimento. Regras para Análise de Sementes. Secretaria de Defesa Agropecuária. MAPA, Brasília, 2009. 399p.

CARVALHO, N. M.; NAKAGAWA, J. Sementes: ciência, tecnologia e produção. 5.ed. Jaboticabal: FUNEP, 2012. $590 \mathrm{p}$.

DUARTE, M. L. R.; ALBUQUERQUE, F. C.; SANHUEZA, R. M. V.; VERZIGNASSI, J. R.; KONDO, N. Etiologia da podridão do coleto de Brachiaria brizantha em pastagens da Amazônia. Fitopatologia Brasileira, Brasília, v. 32, n. 3, p. 261-265, Maio. 2007.

EUCLIDES, V. P. B.; VALLE, C. B. do; MACEDO, M. C. M.; ALMEIDA, R. G. de; MONTAGNER, D. B.; BARBOSA, R. A. Brazilian scientific progress in pasture research during the first decade of XXI century.

Revista Brasileira de Zootecnia, Viçosa, v. 39, supl. spec, p. 151-168, 2010.

FARIAS, C. R. J.; LUCCA-FILHO, O. A.; PIEROBOM, C. R.; PONTE, E. M. D. Qualidade sanitária de sementes de aveia-preta (Avena strigosa Schreb.) produzidas no estado do Rio Grande do Sul, safra 1999/2001. Revista Brasileira de Sementes, Londrina, v. 24, n. 1, p. 1-4, 2002.

FAVORETO, L.; SANTOS, J. M.; CALZAVARA, S. A.; LARA, L. A. Estudo fitossanitário, multiplicação e taxonomia de nematoides encontrados em sementes de gramíneas forrageiras no Brasil. Nematologia Brasileira, Piracicaba, v. 35, n. 2, p. 1-2, Junho. 2011.

FIGUEIREDO-FILHO, D. B.; SILVA-JÚNIOR, J. A. Desvendando os mistérios da correlação de Pearson (r). Revista Política Hoje, Recife, v. 18, n. 1, p. 115-146, 2009.

FONSÊCA-NETO, J.; DANTAS, A. M. M.; SILVA, F. H. A.; CRUZ, B. L. S.; AMBRÓSIO, M. M. Q.; NASCIMENTO, S. R. C. Efeito de adubo verde e Trichoderma harzianum na sobrevivência de Fusarium solani e no desenvolvimento do meloeiro. Revista Agro@mbiente On-line, Boa vista, v. 10, n. 1, p. 44-49, 2016.

GALBIERI, R.; URASHIMA, A. S. Caracterização, compatibilidade e ocorrência de reprodução sexual entre isolados de Pyricularia grisea de diferentes hospedeiros. Summa phytopathologica, Botucatu, v. 34, n. 1, p. 22-28, Jan/Fev. 2008.

GUIMARÃES, L. R. A.; MARCHI, C. E.; FERNANDES, C. D.; JERBA, V. F.; BUENO, M. L.; TRENTIN, R. A.; FABRIS, L. R. Fungos associados às sementes comerciais de braquiária. In: JORNADA CIENTÍFICA 
DA EMBRAPA GADO DE CORTE, 2., 2006, Campo Grande. Anais... Campo Grande: Embrapa Gado de Corte, 2006. p. 1-2.

HENNING, F. A.; JACOB JUNIOR, E. A.; MERTZ, L. M.; PESKE, S. T. Qualidade sanitária de sementes de milho em diferentes estádios de maturação. Revista brasileira de sementes, Londrina, v. 33, n. 2, p. 316-321, 2011.

LASCA, C. C.; VECHIATO, M. H.; KOHARA, E. Y. Controle de fungos de sementes de Brachiaria spp.: eficiência de fungicidas e influência do período de armazenamento de sementes tratadas sobre a ação desses produtos. Arquivos do Instituto Biológico, São Paulo, v. 71, n. 4, p. 465-472, 2004.

MALLMANN, G.; VERZIGNASSI, J. R.; FERNANDES, C. D.; SANTOS, J. M.; VECHIATO, M. H.; INÁCIO, C. A.; BATISTA, M. V.; QUEIROZ, C. A. Fungos e nematoides associados a sementes de forrageiras tropicais. Summa Phytopathologica, Botucatu, v. 39, n. 3, p. 201-203, Jul/Set. 2013.

MARCHI, C. E.; BORGES, M. F.; ARIAS, A. M. S.; FERNANDES, C. D.; JERBA, V. F.; BUENO, M. L. Patologia de sementes de forrageiras tropicais. Summa Phytopathologica, Botucatu, v. 32, Supl. p. 81, 2006.

MARCHI, C. E. FERNANDES, C. D.; JERBA, V. F.; BORGES, M. F.; LORENZETTI, E. R. Brachiaria brizantha: novo hospedeiro de Magnaporthe grisea. Pasturas Tropicales, Cali, v. 27, n. 2, p. 52-54, 2005.

MARCHI, C. E.; FERNANDES, C. D.; BUENO, M. L.; BATISTA, M. V.; FABRIS, L. R. Microflora fúngica de sementes comerciais de Panicum maximum e Stylosanthes spp. Semina Ciências Agrárias, Londrina, v. 31, n. 3, p. 575-584, Jul/Set. 2010a.

MARCHI, C. E.; FERNANDES, C. D.; BUENO, M. L.; BATISTA, M. V.; FABRIS, L. R. Fungos veiculados por sementes comerciais de braquiária. Arquivos do Instituto Biológico, São Paulo, v. 77, n. 1, p. 65-73, $2010 \mathrm{~b}$.

PREVIERO, C. A.; GROTH, D.; SOAVE, J. Sobrevivência de Drechslera spp. em sementes de Brachiaria brizantha (Hochst.ex A. Rich.) Stapf armazenadas em ambiente natural. Revista Brasileira de Sementes, Londrina, v. 21, n. 2, p. 148-154, 1999. https://doi.org/10.17801/0101-3122/rbs.v21n2p148-154

RAMOS, P. D.; BARBOSA, R. F.; VIEIRA, B. G. T. L.; PANIZZI, R. C.; VIEIRA, R. D. Infecção por Fusarium graminearum e Fusarium verticillioides em sementes de milho. Pesquisa Agropecuária Tropical, Goiânia, v. 44, n. 1, p. 24-31, 2014. https://doi.org/10.1590/S1983-40632014000100011

SALGADO-NETO, G.; VAZ, M. A. B.; GUEDES, J. V. C.; MUNIZ, M. F. B.; BLUME, E. Fusarium oxysporum dispersion by larvae of Cyclocephala modesta, Dyscinetus gagates and Diloboderus abderus in Brazil. Ciência Rural, Santa Maria, v.46, n.6, p. 943-949, 2016. http://dx.doi.org/10.1590/01038478cr20150471.

SANTOS, G. R.; TSCHOEKE, P. H.; SILVA, L. G.; SILVEIRA, M. C. A. C.; REIS, H. B.; BRITO, D. R.; CARLOS, D. S. Sanity analysis, transmission and pathogenicity off fungi associated with forage plant seeds in tropical regions of Brazil. Journal of Seed Science, Londrina, v. 36, n. 1, p. 54-62, 2014. https://doi.org/10.1590/S2317-15372014000100007

SBALCHEIRO, C. C.; ROVERI, J. S. C. B.; BARBOSA, J. C. R. C. M. Physiological and sanitary quality, and transmission of fungi associated with Brachiaria brizantha (Hochst. ex. A. Rich.) Stapf seeds submitted to thermal and chemical treatments. Journal of Seed Science, Londrina, v. 36, n. 4, p. 443-450, 2014. http://dx.doi.org/10.1590/2317-1545v36n41032. 
VECHIATO, H. M.; APARECIDO, C. C. Fungos em sementes de gramíneas forrageiras: restrição fitossanitária e métodos de detecção. Comunicado Técnico do Instituto Biológico: São Paulo. Centro de Pesquisa e Desenvolvimento de Sanidade Vegetal, n. 89, 2008.

VERZIGNASSI, J. R.; POLTRONIERI, L. S.; BENCHIMOL, R. L.; FRANÇA, S. K. S.; CARVALHO, E. A.; FERNANDES, C. D. Pyricularia grisea: novo patógeno em Brachiaria brizantha cv. Marandú no Pará.

Summa Phytopathologica, Botucatu, v. 38, n. 3, p. 254, July/Sept. 2012. 